\title{
PENGARUH MODAL SENDIRI DAN MODAL PINJAMAN TERHADAP SISA HASIL USAHA (SHU) KOPERASI KOTA SUKABUMI
}

\author{
Tria Rohmansyah ${ }^{1)}$, Sudarijati $^{2)}$ \\ Program Studi Manajemen Fakultas Ekonomi Universitas Djuanda Bogor \\ Email : triarohmansyah25@gmail.com,atikmartono@gmail.com \\ Correpondence author : atikmartono@gmail.com
}

\begin{abstract}
This research purpose how the influence of their own capital and loan capital of net income cooperative in Sukabumi City. This research is quantitative descriptive study using multiple regression analysis. The sampling technique used was purposive sampling where the sampling is based on certain criteria. From the established criteria, obtained 11 (eleven) sample cooperative in sukabumi city with the observation period of 2 (two) years for each sample cooperative. The research analysis tools using multiple regression analysis. Simultaneous hypothesis testing using the $F$ and partial test using t-test with a probability level of 5 percent $(0,05)$. F-test result explain that the own capital and loan capital Simultaneous have a positive and significant effect on net income cooperative. $t$-test results showed that the own capital have a positive and significant effect on net income. While loan capital is not have significant impact on net income cooperative in Sukabumi City.
\end{abstract}

Key words : Equity, Loan Capital, Net Profit Margin

\begin{abstract}
ABSTRAK
Penelitian ini bertujuan untuk mengetahui bagaimana pengaruh modal sendiri dan modal pinjaman terhadap sisa hasil usaha (SHU) koperasi di Kota Sukabumi. Desain penelitian yang digunakan adalah penelitian kuantitatif dengan menggunakan data sekunder. Teknik pengambilan sampel yang digunakan adalah purposive sampling dimana pengambilan sampel didasarkan pada kriteria tertentu. Dari kriteria yang telah ditetapkan, diperoleh 11 (sebelas) sampel koperasi di Kota Sukabumi dengan periode pengamatan selama 2 (dua) tahun untuk setiap koperasi sampel. Alat analisis penelitian ini menggunakan analisis regresi berganda. Pengujian hipotesis secara simultan menggunakan uji $\mathrm{F}$ dan secara parsial menggunakan uji t dengan tingkat probabilitas sebesar 5 persen $(0,05)$. Hasil penelitian uji $\mathrm{F}$ menerangkan bahwa modal sendiri dan modal pinjaman secara bersama-sama berpengaruh positif dan signifikan terhadap sisa hasil usaha. Hasil uji t menunjukan bahwa modal sendiri berpengaruh positif dan signifikan terhadap sisa hasil usaha, sedangkan modal pinjaman tidak berpengaruh signifikan terhadap sisa hasil usaha koperasi di Kota Sukabumi.
\end{abstract}

Kata kunci : modal sendiri, modal pinjaman, sisa hasil usaha. 


\section{PENDAHULUAN}

Suatu negara bisa menaikan perekonomianya apabila terdapat koperasi didalamnya. koperasi berperan penting bagi masyarakat diantaranya koperasi dapat menambah pendapatan masyarakat khususnya angggota koperasi tersebut, dapat mengurangi kesenjangan, menambah lapangan kerja, dan memeratakan pendapatan. Atas dasar itu, di Indonesia koperasi sangat diperlukan oleh masyarakat dan pemeritah. Laporan tahunan Kementrian Koperasi \& UMKM Republik Indonesia menyebutkan selama periode 20092014 anggota koperasi telah meningkat sebanyak 7.203 .682 orang atau 19,76 persen, dan jumlah seluruh anggota koperasi sebanyak 36.443 .953 orang. Koperasi juga berhasil memperoleh SHU sebesar Rp.14,8 Triliun. Menurut catatan BPS (Badan Pusat Statistik) tahun 2013, UMKM dan Koperasi berhasil memperkerjakan 85,4 juta pekerja Indonesia. Tahun 2014 UMKM dan Koperasi berkontribusi meningkatkan PDB (Produk Domestik Bruto) sebesar Rp 1,778 triliun (53\%) dari PDRB Indonesia.

Koperasi Indonesia sering menghadapi masalah permodalan. Kondisi tersebut dikarenakan koperasi belum memiliki banyak anggota, belum mempunyai kegiatan usaha, kurangnya tenaga kerja profesional, rendahnya penguasaan dan pemanfaatan tekhnologi yang efisien, serta rendahnya keahlian SDM yang dimiliki. Sebagai badan usaha, kinerja manajemen operasional dan keuangan sangat menentukan kinerja koperasi. Koperasi dianggap berhasil apabila SHU terus meningkat setiap tahunnya. Sehingga dapat memperkuat struktur financial koperasi tersebut. Besar-kecilnya modal koperasi menentukan perkembangan usaha koperasi. (Partomo, $2004: 82$ ).

Komitmen untuk menumbuhkan perekonomian berbasis koperasi tidak hanya dikota-kota besar saja di Indonesia, namun juga didaerah kecil, salah satunya Kota Sukabumi. Menurut data Dinas Prindustrian,
Perdaangan Dan Koperasi (Disperindagkop) Kota Sukabumi sejak tahun 2015 kurang lebih ada 412 unit, tetapi tidak semua koperasi yang terdata dapat berjalan dan berkembang secara aktif. Berikut data koperasi yang terdata di Disperindagkop Kota Sukabumi:

Tabel 1. Jumlah Koperasi Kota Sukabumi Tahun 2016

\begin{tabular}{clcc}
\hline No & Keterangan & Jumlah (unit) & $\begin{array}{c}\text { Persentase } \\
(\%)\end{array}$ \\
\hline 1 & $\begin{array}{l}\text { Koperasi yang } \\
\text { terdaftar }\end{array}$ & 412 & 100 \\
2 & $\begin{array}{l}\text { Koperasi aktif } \\
3\end{array}$ & 67 & 16 \\
& $\begin{array}{l}\text { Koperasi yang } \\
\text { melakukan RAT }\end{array}$ & 54 & 13 \\
3 & $\begin{array}{l}\text { Koperasi tidak } \\
\text { aktif }\end{array}$ & 190 & 46 \\
4 & $\begin{array}{l}\text { Koperasi } \\
\text { dibubarkan }\end{array}$ & 101 & 25 \\
\end{tabular}

Sumber : Dinas Perindustrian, Perdagangan \& Koperasi Kota Sukabumi 2016

Masalah permodalan dan manajerial yang tidak baik adalah kendala dihadapi koperasi Kota Sukabumi sehingga banyak koperasi dibubarkan. Selain itu koperasi yang aktif tidak semua menjalankan rapat anggota tahunan. sehingga menyulitkan pihak Diskopdagrin Kota Sukabumi dalam melakukan pengawasan. Untuk melihat bagaimana kondisi SHU dan permodalan koperasi Kota Sukabumi, berikut ini koperasi yaang melaksanakan RAT tepat waktu. Terdapat 11 (sebelas) koperasi yang aktif melakukan RAT (dapat dilihat ditabel 2). Hasil dari tabel tersebut memperlihatkan jika modal sendiri sebesar Rp.14.583.943.215 atau 49 persen dari total modal, sedangkan jumlah besarnya modal pinjaman Rp. 14.663.736.772 atau 51 persen dari total modal. Selain itu, jumlah rata-rata modal sendiri sebesar Rp. 1.325.813.020 dan yang memenuhi ratarata/diatas rata-rata modal sendiri sebanyak 2 koperasi, sedangkan yang kurang dari rata-rata sebanyak 9 koperasi.dan rata-rata modal pinjaman adalah sebesar Rp.1.333.066.979 
Tabel 2. SHU dan Modal Koperasi Kota Sukabumi 2015

\begin{tabular}{rcrrr}
\hline No. & Nama Koperasi & $\begin{array}{c}\text { Modal Sendiri } \\
(\mathrm{Rp})\end{array}$ & $\begin{array}{c}\text { Modal Pinjaman } \\
(\mathrm{Rp})\end{array}$ & \multicolumn{1}{c}{\begin{tabular}{c}
\multicolumn{1}{c}{ SHU } \\
$(\mathrm{Rp})$
\end{tabular}} \\
\hline 1 & Mitra Setia & 1.208 .169 .630 & 542.473 .533 & 64.246 .907 \\
2 & Kokasyifa & 1.225 .851 .703 & 312.427 .320 & 353.669 .814 \\
3 & BMT Ibadurahman & 5.813 .429 .186 & 6.751 .909 .775 & 140.868 .135 \\
4 & Usaha Kita & 1.090 .147 .912 & 1.171 .478 .366 & 182.873 .532 \\
5 & Kowarsda & 469.131 .882 & 577.525 .778 & 33.526 .449 \\
6 & Primkopad Kodim & 1.589 .988 .358 & 2.808 .194 .140 & 100.821 .733 \\
7 & Mina Karya & 894.034 .385 & 708.845 .440 & 325.450 .000 \\
8 & Warga & 1.113 .863 .419 & 325.805 .635 & 63.032 .390 \\
9 & Dewi Sartika & 792.712 .985 & 792.712 .985 & 72.662 .529 \\
10 & Kerukunan & 58.574 .655 & 216.735 .000 & 18.050 .400 \\
11 & Triguna & 328.039 .100 & 455.628 .800 & 23.645 .873 \\
\hline \multicolumn{7}{c}{ Jumlah } & 14.583 .943 .215 & 14.663 .736 .772 & 1.378 .847 .762 \\
\hline
\end{tabular}

Sumber : Dinas Perindustrian, Perdagangan \& Koperasi Kota Sukabumi 2016

dan yang memenuhi rata-rata/diatas rata-rata sebanyak 2 koperasi, sedangkan yang kurang dari rata-rata sebanyak 9 koperasi.

Hasil tersebut mengambarkan bagaimana struktur modal koperasi belum proporsional, selain itu berdasarkan Tabel 2 menunjukan bahwa koperasi yang jumlah modalnya besar tidak dapat menghasilkan SHU yang besar juga, artinya koperasi belum mampu memanfaatkan jumlah modal besarnya guna memperoleh SHU yang tinngi, kondisi tersebut bertentangan dengan pendapat Sukamdiyo (1997 : 82), “mengatakan bahwa dengan bertambahnya modal maka SHU akan meningkat".

Salah satu permasalahan koperasi adalah upaya peningkattan permodalan dan pemanfaatan modal tersebut guna memperoleh SHU yang tinggi. Modal yang dimanfaatkan untuk operasional koperasi dapat menentukan besarnya perolehan SHU. Sehingga sangat penting untuk tau faktor yang mempengaruhi SHU.

\section{MATERI}

\section{Modal Sendiri}

"modal yang didapatkan dari anggota koperasi atau dari bagian yang disisihkan oleh peserta atau pemilik". (Riyanto,2001:21). Sedangkan pada UU Nomor 25/92, menyebutkan modal sendiri terdiri dari simpanan wajib anggota, simpanan pokok anggota, cadangan, dan hibah. Pada dasarnya modal sendiri disetorkan anggota untuk dimanfaatkan koperasi sebagai biaya operasional koperasi, Pemilik koperasi adalah anggota koperasi itu sendiri.

\section{Modal pinjaman}

Dalam Undang-Undang Nomor 7/1992, pinjaman merupakan uang yang disediakan didasarkan persyaratan pinjaman antara yang meminjam dan yang memberi pinjaman yang mengharuskan peminjam membayar hutang setelah batas waktu yang ditetapkan dengan jumlah bunga/imbalan/penghasilan dari hasil keuntungan. Menurut Riyanto (2001:227), modal pinjaman yaitu uang yang diterima dari luar yang sifatnya sementara, dan bagi koperasi uang itu merupakan hutang yang harus dikembalikan. Undang-Undang No. 25/1992 menyebutkan bahwa modal pinjaman 
bisa berasal dari: anggota, bank atau bukan bank, koperasi lain dan atau anggotanya, surat utang, dan sumber-sumber lain yang sah.

\section{Sisa/Selisih Hasil Usaha}

Menurut Kusnadi dan Hendar (1999:98), selisih hasil usaha merupakan pemasukan yang diterima koperasi selama satu tahun, dikurangi dengan pengeluaran dalam satu tahun. SHU berdasarkan pengertian tersebut, jumulah SHU yang didapatkan setiap anggota berbeda-beda, sesuai dengan partisipasi anggota tersebut. Pembagian SHU koperasi dilakukan dengan sebanding dan adil sesuai kontribusi setiap anggota, dasar hukumnya Undang-Undang No. 25, Tahun 1992, Pasal 5 ,ayat 1 , tentang Perkoperasian.

\section{Pengertian Koperasi}

Co-operation yang berarti usaha bersama. Menurut Madlenta (2009:19), koperasi merupakan badan hukum dengan usaha bersama, dan anggota sebagai pemilik.

Koperasi sehat atau mandiri memiliki 13 kriteria yaitu :

1. Minimal 25 persen penduduk dewasa menjadi anggota

2. Minimal 60 persen bisnisnya harus dengan anggota

3. 3 (tiga) tahun berturut-turut mengadakan RAT

4. Anggota, pengurus dan pengawas harus anggota KUD

5. Minimal modal sendiri Rp 25.000.000,-

6. Volume usaha harus sebanding dengan anggota, minimal Rp 25.000/anggota pertahun

7. Pendapatan kotor harus bisa menutup biaya.

8. Kelayakan sarana usaha dan dikelola sendiri.

9. Tidak telat bayar hutang

10. Laporan keuangan telah diaudit dengan hasil layak tanpa cacatan

11. Deviasi usaha dari rencana maksimal $20 \%$

12. Likuiditas $150 \%-200 \%$, dan solvabilitas minimal $100 \%$
13. Pengelolaan KUD harus dijalankan dengan bersih tanpa penyelewengan.

\section{Kerangka Pemikiran}

Modal sendiri menentukan perolehan SHU koperasi, Karena modal yang bisa digunakan koperasi semakin banyak dan bisa dimanfaatkan dengan lebih optimal. Dana/modal pinjaman atau luar koperasi hendaknya perlu dipertimbangkan. Rozi dan Hendri (1997: 88) menyebutkan "SHU diperoleh dari pendapatan dikurangi dengan total biaya". SHU dipengaruhi oleh : modal sendiri, kemampuan pengurus, partisipasi anggota dan banyaknya usaha yang dijalankan. Kerangka pemikiran menjelaskan hubungan setiap variabel $\mathrm{X}_{1}$ dan $\mathrm{X}_{2}$ terhadap selisih hasil usaha (Y). Untuk lebih jelasnya dapat dilihat pada gambar 1 .

\section{Hipotesis}

Hipotesis dinyatakan bahwa variabel $\mathrm{X}$ (modal sendri \& modal pinjaman) secara bersama-sama berpengaruh positif dan nyata pada variabel Y (SHU). selanjutnya seluruh variabel $\mathrm{X}$ secara parsial memiliki pengaruh positif dan nyata terhadap variabel $\mathrm{Y}$

\section{METODE PENELITIAN}

Penelitian dilakukan guna mendapatkan gambaran tentang pengaruh variable $X$ terhadap variabel Y koperasi Kota Sukabumi. Metode penelitiannya adalah metode deskriptif dan asosiatif. Metode deskriptip ialah penelitian kaitannya dengan pertanyaanpertanyaan terhadap kondisi variabel bebas, hanya satu variabel ataupun lebih. (Sugiyono, 2013 : 59). Sedangkan jenis datanya sekunder yaitu berupa laporan keuangan koperasi tahun 2015-2016. Objek penelitian dilakukan pada koperasi yang tercatat pada dinas perindustrian, perdagangan dan koperasi Kota Sukabumi. 
Populasi yang digunakan ialah koperasi aktif

Penelitian terdahulu :

- Rahayu (2011), "Pengaruh Modal Sendiri dan Modal Pinjaman Terhadap Perolehan Sisa Hasil Usaha pada KPRI di Kabupaten Pati”.

- Indriani (2012), "Pengaruh Pertumbuhan Modal Koperasi dan Kinerja Koperasi Terhadap Perkembangan Sisa Hasil Usaha koperasi pada Koperasi Pegawai.

- Suteja (2016), "Pengaruh Jumlah Modal Sendiri dan Jumlah Modal Pinjaman Terhadap Perolehan Sisa Hasil Usaha Pada KPN Praja Mukti Kantor Bupati Buleleng Tahun 2006-2015"

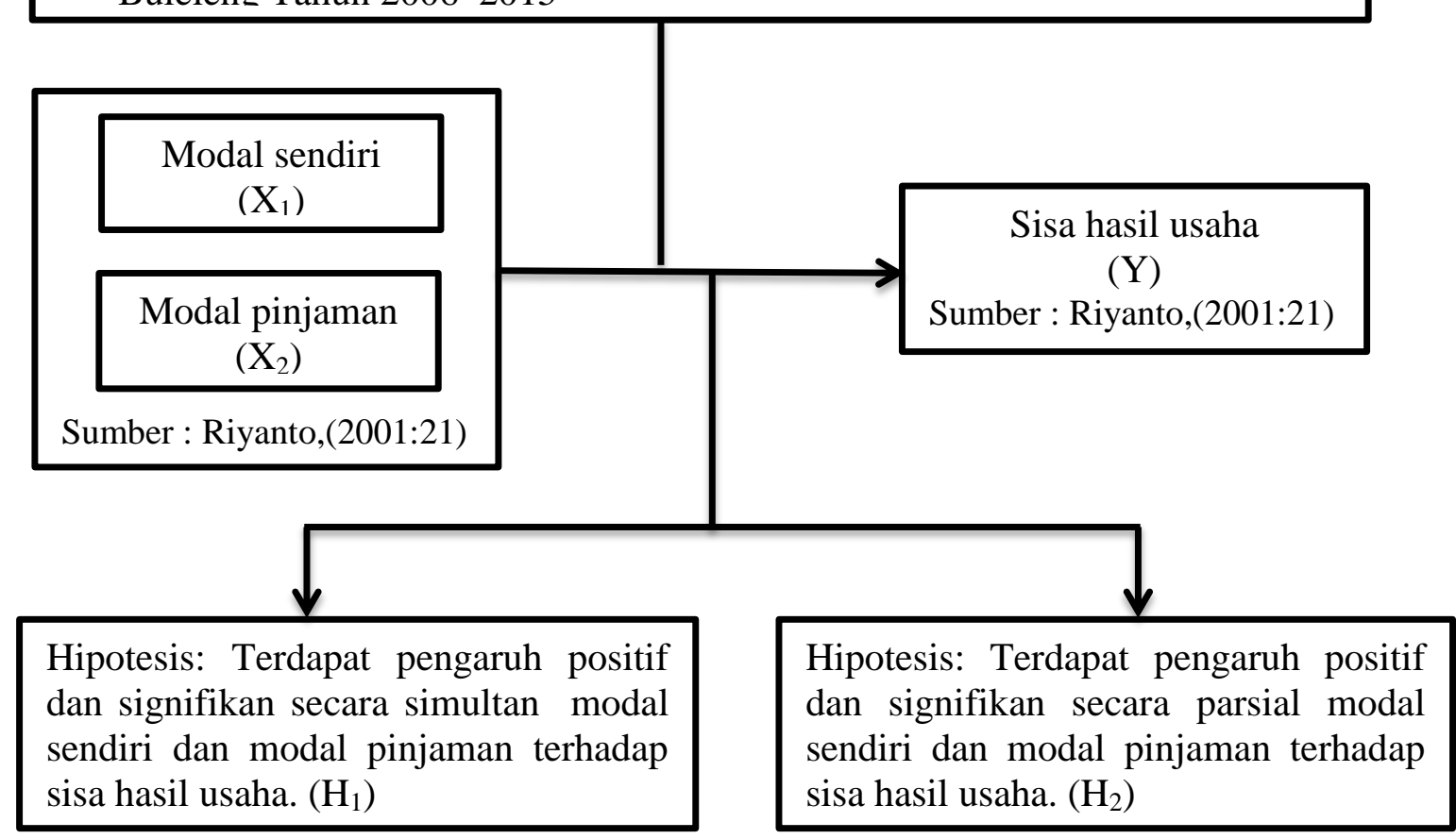

Gambar 1. Kerangka Pemikiran

\section{Operasionalisasi Variabel}

Variabel yang dipakai yaitu modal sendiri $\left(\mathrm{X}_{1}\right)$, modal pinjama $\left(\mathrm{X}_{2}\right)$. serta variabel terikat ialah sissa hasill ussaha (Y). Operasionalisasi variabel terdapat di Tabel 1.

\section{Populasi, Sampel dan Tehnik Pengambilan Sampel}

yang terdaftar pada Dinas Perindustrian, Perdagangan dan Koperasi (Disperindagkop) Kota Sukabumi yaitu sebanyak 121 koperasi. Sugiyono (2013:120) sampel ialah sebagian karateristik yang dipunyai populasi. Teknik pengambilan sampelnya yaitu purposive sampling. Dalam teknik tersebut penentuan 
sampel didasarkan pada kriteria tertentu. 7. Koperasi Mina Karya.

(Sugiyono, $2013: 126$ )

8 Knneraci W/arca

Tabel 3. Operasionalisasi Variabel

\begin{tabular}{|c|c|c|c|}
\hline Variabel & Konsep Variabel & Indikator & $\begin{array}{l}\text { Skala } \\
\text { Ukur }\end{array}$ \\
\hline $\begin{array}{l}\text { Modal sendiri } \\
\qquad\left(\mathrm{X}_{1}\right)\end{array}$ & $\begin{array}{l}\text { Modal sendiri yaitu modal perusahaan } \\
\text { yang diterima dari internal (cadangan, } \\
\text { keuntungan) atau yang diambil dai } \\
\text { bagian anggota atau pemilik (saham, } \\
\text { modal anggota, dll).(Riyanto, } 2001 \text { : } \\
\text { 21) }\end{array}$ & $\begin{array}{l}\text { 1. Simpanan pokok } \\
\text { 2. Simpanan wajib } \\
\text { 3. Dana cadangan } \\
\text { 4. Donasi dan hibah }\end{array}$ & $\begin{array}{l}\text { Rasio } \\
\text { Rasio } \\
\text { Rasio } \\
\text { Rasio }\end{array}$ \\
\hline $\begin{array}{l}\text { Modal pinjaman } \\
\qquad\left(\mathrm{X}_{2}\right)\end{array}$ & $\begin{array}{l}\text { Modal pinjaman ialah modal dari luar } \\
\text { koperasi yang bersifat sesaat bagi } \\
\text { koperasi, dan bagi koperasi modal } \\
\text { tersebut sifatnya hutang dan wajib di } \\
\text { kembalikan. (Riyanto, } 2001: 227 \text { ) }\end{array}$ & $\begin{array}{l}\text { 1. Pinjaman anggota } \\
\text { 2. Pinjaman dari koperasi } \\
\text { lain atau anggotanya } \\
\text { 3. Bank dan non Bank } \\
\text { 4. Penerbitan obligasi } \\
\text { atau surat berharga } \\
\text { lainnya }\end{array}$ & $\begin{array}{l}\text { Rasio } \\
\text { Rasio }\end{array}$ \\
\hline $\begin{array}{l}\text { Sisa hasil usaha } \\
\text { (Y) }\end{array}$ & $\begin{array}{l}\text { Sisa hasil usaha ialah pemasukan } \\
\text { yang didapatkan selama setahun } \\
\text { setelah dikurangi biaya, penyusutan, } \\
\text { dan biaya lain termasuk pajak ( UU } \\
\text { No. } 25 \text { tahun 1992) }\end{array}$ & $\begin{array}{l}\text { 1. Total penerimaan } \\
\text { 2. Total biaya dan beban }\end{array}$ & $\begin{array}{l}\text { Rasio } \\
\text { Rasio }\end{array}$ \\
\hline
\end{tabular}

Adapun kriteria yang ditetapkan dalam pengambilan sampel penelitian ini diantaranya adalah :

1. Koperasi yang tercatat pada Dinas Perindustrian, Perdagangan dan Koperasi (Disperindagkop) Kota Sukabumi.

2. Jenis usaha koperasi adalah simpan pinjam.

3. Mempunyai modal pinjaman dan modal sendiri

4. Koperasi melakukan RAT tepat waktu.

5. Beranggotakan minimal 50 orang.

Berdasarkan kriteria tersebut maka koperasi yang tercatat pada Dinas Perindustrian, Perdagangan, dan Koperasi (Disperindagkop) Kota Sukabum yang dapat diteliti sebanyak 11 (sebelas) koperasi yang dapat dilihat berikut ini :

1. Koperasi Mitra Setia.

2. Koperasi Kokasyifa.

3. Koperasi Ibaadurrahman.

4. Koperasi Usaha Kita.

5. Koperasi Kowarsda.

6. Koperasi Prim Kopad Kodim.
9. Koperasi Dewi Sartika.

10. Koperasi Kerukunan.

11. Koperasi Triguna

\section{Uji Asumsi Klasik}

Menurut Gujarati (2003 : 97) tujuannya untuk melihat bahwa hasil penelitian adalah valid secara teori tidak bias, konsisten dan penafsiran koefisien regresinya efisien. Untuk menguji hipotesis, hasil perkiraan akan ditaksir dengan cara 4 (empat) pengujian, yaitu :

1. Uji normalitas

Digunakan metode grafik histogram, grafik P-Plot serta uji Kolmogorov-Smirnov. Hasil uji menunjukan bahwa data telah terdistribusi normal karena kurva yang didapat berbentuk simetris terhadap mean (U).

2. Uji multikoliniaritas

Menurut Sunyoto (2009 : 82), dikatakan bahwa tidak terjadi multikolinearitas apabila nilai tolerance $>0,05$ atau VIF $<5$, Model regresi linier berganda harus tidak 
ada gejala multikolinearitas supaya bisa digunakan untuk penelitian.

3. Uji heteroskedastisitas

Berdasarkan hasil uji heteroskedastisitas dengan menggunakan scatterplot diketahui bahwa pencaran data tidak menunjukan pola tertentu dan menyebar dengan acak. Sehingga disimpulkan tidak terjadi kondisi heteroskedastisitas pada data

4. Uji autokorelasi

Hasil uji autokorelasi, tidak adanya autokorelasi antara variabel bebas, karena nilai Durbin-Watson yang didapat sebesar 1,988 dimana $-2<1,988<2$

\section{Analisis Regresi Berganda}

Data-data yang didapat akan dianalisis secara verifikasi dengan menggunakan uji statistik. Pengujian hipotesis yang ada akan digunakan regresi berganda untuk dapat melihat pengaruh variabel bebas/independent terhadap variabel independent, dengan cara berikut ini:

1. Menentukan model jalur berdasarkan paradigma penelitian.

Prosedur analisis data pertama-tama adalah menentukan paradigma penelitian berdasarkan kerangka pemikiran. Apabila dituangkan kedalam suatu model maka hubungan antara variabel dapat diungkapkan kedalam model penelitian sebagai berikut :

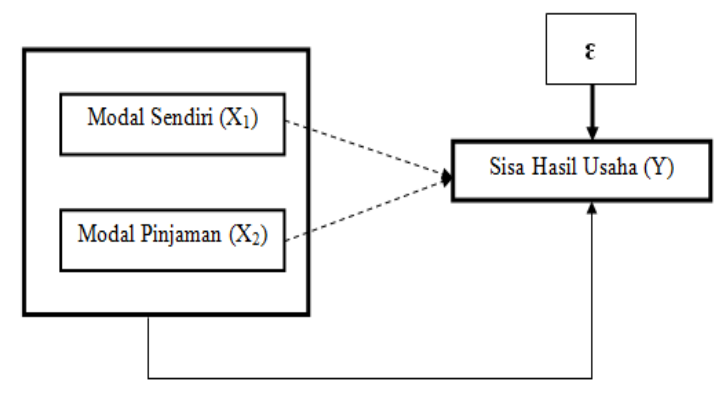

Gambar 2.

Hubungan Antar Variabel Penelitian

Keterangan:

$\varepsilon \quad=$ Variabel yang tidak diteliti

- - - - - - Pengaruh secara parsial

$\longrightarrow=$ Pengaruhsecara simultan $\longrightarrow=$ Pengaruh error

Persamaan strukturalnya

Untuk mengukur pengaruh antara suatu variabel dependent dengan dua variabel independent, fungsi dalam regresi sebagai berikut:

$$
Y=a+\beta_{1} X_{1}+\beta_{2} X_{2}+e
$$

Keterangan:

$\mathrm{Y}=$ Sisa/selisih hasil usaha

$A \quad=$ Bilangan konstanta

$\beta_{1} \quad=$ Koefisien regresi variabel modal sendiri

$\beta_{2}=$ Koefisien regresi variabel modal pinjaman

\section{Analisis Korelasi Berganda}

Untuk melihat bagaimana hubungan $\mathrm{X}_{1}$ dan $\mathrm{X}_{2}$ terhadap variabel $\mathrm{Y}$. Dari rumus analisis korelasi diatas, maka akan diperoleh nilai $r$ yang besarnya antara -1, 0 sampai 1 . Notasi ini menggunakan korelasi antara variabel-variabel yang diuji dalam penelitian. Kriterianya sebagai berikut

Tabel 4. Interpretasi Terhadap Nilai $r$

\begin{tabular}{cl}
\hline $\begin{array}{c}\text { Interval Nilai } \\
\mathrm{r}\end{array}$ & \multicolumn{1}{c}{ Interpretasi } \\
\hline $0,001-0,200$ & Sangat Lemah \\
$0,201-0,400$ & Lemah \\
$0,401-0,600$ & Cukup Kuat \\
$0,601-0,800$ & Kuat \\
$0,801-1,000$ & Sangat Kuat \\
\hline
\end{tabular}

Sumber : Sugiyono, 2015

Koefisien determinasi menurut Ghozali (2005), dapat digunakan dalam mengukur kemampuan model untuk menjelaskan variasi variabel terikat yang dengan menggunakan:

$\mathrm{KD}=\mathrm{r}^{2} \times 100 \%$

dimana:

KD : koefisien determinasi

R : koefisien korelasi 


\section{Pengujian Hipotesis}

Untuk mengetahui kebenaran dari perhitungan analisis korelasi, maka diperlukan pengujian hipotesis. Pengujian ini akan menggunakan distribusi t, dengan keyakinan (1- $\alpha$ ) sebesar 95 persen dan derajad kebebasan (df) sebesar n-21 untuk menentukan hipotesis diterima atau ditolak.

Hasil dari pengujian hipotesis tersebut adalah:

a) Bila $t_{\text {hitung }}$ lebih kecil dari atau sama dengan $\mathrm{t}_{\text {tabel }}\left(\mathrm{t}_{\text {hitung }} \leq \mathrm{t}_{\text {tabel }}\right)$ pada $\alpha=0,05$ maka Ho ditterima dan Ha ditolak.

b) Bila $t_{\text {hitung }}$ lebih bessar dari $t_{\text {tabel }}\left(t_{\text {hitung }}>\right.$ $\mathrm{t}_{\text {tabel}}$ ) pada $\alpha=0,05$ maka Ho ditolak dan Ha diterima

\section{HASIL DAN PEMBAHASAN}

Modal koperasi dipakai untuk meningkatkan kesejahteraan dan ekonomi anggota. Modal sendiri dapat dipakai untuk mempertahankan likuiditas, memberikan pinjaman, pembelian aset, mengganti kerugian koperasi, dan menambah kepercayaan pada pemberi kredit: meningkat dengan persentase sebesar 14 persen. Artinya koperasi mencari modal dari sumber internal koperasi cukup baik. Koperasi mengalami pertumbuhan modal sendiri meningkat ada sebanyak 8 (delapan) koperasi, Peningkatan modal sendiri paling besar terjadi pada Koperasi Mina Karya dengan persentase peningkatan sebesar 105 persen dan peningkatan terendah terjadi pada koperasi Kokasyifa dengan persentase peningkatan sebesar 4\%. Sedangkan penurunan modal sendiri terjadi pada 3 (tiga) koperasi. Penuruan modal sendiri terbesar terjadi pada Koperasi BMT Ibadurahman dengan persentase penurunan sebesar 88, sedangkan penurunan terrendah adalah Koperasi Dewi Sartika sebesar 8 persen. Perubahan modal sendiri yang. Menurun atau meningkatnya modal itu adalah dampak dari perubahan struktur modal koperasi. Selain menggunaka modal sendiri koperasi juga menggunakan modal pinjaman dalam struktur modalnya. Berikut ini merupakan tabel tentang kondisi pertumbuhan modal pinjaman

Tabel 5.

Pertumbuhan Modal Sendiri Koperasi Kota Sukabumi Periode 2015-2016

\begin{tabular}{ccrcc}
\hline \multirow{2}{*}{ No } & Koperasi & \multicolumn{2}{c}{ Modal Sendiri } & \multirow{2}{*}{ Pertumbuhan (\%) } \\
\cline { 3 - 4 } & & $\mathbf{2 0 1 5}$ & $\mathbf{2 0 1 6}$ & \\
\hline 1 & Mitra Setia & 1.208 .169 .630 & 1.707 .200 .009 & 41 \\
2 & Kokasyifa & 2.799 .053 .507 & 2.905 .508 .513 & 4 \\
3 & BMT Ibadurahman & 5.813 .429 .186 & 692.530 .832 & $(88)$ \\
4 & Usaha Kita & 701.945 .275 & 933.964 .581 & 33 \\
5 & Kowarsda & 469.131 .882 & 271.645 .391 & $(42)$ \\
6 & Primkopad Kodim & 1.589 .988 .358 & 1.719 .595 .058 & 8 \\
7 & Mina Karya & 894.034 .385 & 1.829 .885 .903 & 105 \\
8 & Warga & 1.113 .863 .419 & 1.214 .377 .418 & 9 \\
9 & Dewi Sartika & 792.712 .985 & 727.068 .985 & $(8)$ \\
10 & Kerukunan & 58.574 .655 & 95.547 .108 & 63 \\
11 & Triguna & 328.039 .100 & 415.488 .834 & 27 \\
\hline \multicolumn{5}{c}{} \\
\hline
\end{tabular}

Berdasarkan Tabel 5 tersebut modal sendiri secara rata-rata terjadi perubahan yang
Sedangkan rataan modal pinjaman terjadi penurunan dengan persentase sebesar 31 
persen. Kondisi tersebut baik bagi koperasi karena dengan menurunnya modal pinjaman berarti ketergantungan koperasi kepada pihak lainnya menurun. Terdapat 9 (sembilan) koperasi mengalami penurunan modal pinjaman. Penuruan modal pinjaman terbesar terjadi pada Koperasi Kowarsda dengan persentase penurunan sebesar 96 persen dan yang penurunannya terendah adalah koperasi Mitra Setia dengan 46 persen. Sedangkan sebanyak 2 (dua) koperasi mengalami peningkatan modal pinjaman. peningkatan modal pinjaman terjadi pada Koperasi Kokasyifa dan Koperasi BMT Ibadurahman dengan persentase peningkatan sebesar 311 persen dan 55 persen. Penurunan modal pinjaman terjadi karena perubahan kondisi modal koperasi. Berikut ini merupakan tabel tentang kondisi pertumbuhan SHU, seperti terlihat pada tabel 6 .
Berdasar rataan SHU koperasi mengalami peningkatan yang relativ besar dengan persentase sebesar 91 persen. Semua koperasi mengalami peningkatan SHU, peningkatan SHU yang paling besar terjadi pada Koperasi Kowarsda dengan persentase peningkatan sebesar 587 persen, dan yang terrendah adalah Koperasi Primkopad Kodim dengan persentase sebesar 3 persen. Peningkatan SHU menunjukan kalau kinerja koperasi tersebut baik, selain itu dengan meningkatnya SHU maka kesejahteraan anggota meningkat.(lihat ditabel 7).

Deskriptif Statistik Variabel Penelitian Tabel 8 tersebut menyajikan informasi nilai minimum, maximum, rata-rata, dan standar deviasidari setiap variabel yang diteliti. Pada variabel modal sendiri diperoleh nilai minimum sebesar Rp. 58.574.655, nilai

Tabel 6.

Pertumbuhan Modal Pinjaman Koperasi Kota Sukabumi Periode 2015-

\begin{tabular}{|c|c|c|c|c|}
\hline \multirow[t]{2}{*}{ No } & \multirow[t]{2}{*}{ Koperasi } & \multicolumn{2}{|c|}{ Modal Pinjaman } & \multirow[t]{2}{*}{$\begin{array}{c}\text { Pertumbuhan } \\
(\%)\end{array}$} \\
\hline & & 2015 & 2016 & \\
\hline 1 & Mitra Setia & 542.473 .533 & 294.854 .497 & (46) \\
\hline 2 & Kokasyifa & 312.427 .320 & 1.284 .212 .899 & 311 \\
\hline 3 & BMT Ibadurahman & 6.751 .909 .775 & 10.482 .879 .665 & 55 \\
\hline 4 & Usaha Kita & 1.171 .478 .366 & 302.551 .450 & (74) \\
\hline 5 & Kowarsda & 577.525 .778 & 25.774 .000 & (96) \\
\hline 6 & Primkopad Kodim & 2.808 .194 .140 & 163.900 .000 & (94) \\
\hline 7 & Mina Karya & 708.845 .440 & 119.400 .000 & (83) \\
\hline 8 & Warga & 325.805 .635 & 68.180 .000 & (79) \\
\hline 9 & Dewi Sartika & 792.712 .985 & 148.774 .000 & (81) \\
\hline 10 & Kerukunan & 216.735 .000 & 65.421 .710 & (70) \\
\hline 11 & Triguna & 455.628 .800 & 53.792 .525 & (88) \\
\hline & Rata-Rata & 1.333 .066 .979 & 1.182 .703 .704 & (31) \\
\hline
\end{tabular}

Sumber : Dinas Perindustrian, Perdagangan \& Koperasi Kota Sukabumi (diolah),2017 
maksimum Rp. 5.813.429.186 dan nilai ratarata sebesar Rp. 1.231.670.720,.32, variabel modal pinjaman memiliki nilai minimum sebesar Rp. 25.774.000, nilai maksimum Rp. 10.482.879.665 dan nilai rata-rata sebesar $\mathrm{Rp}$. 1.257.885.341,73. Sedangkan untuk variabel dependent sisa hasil usaha memiliki memiliki nilai minimum sebesar Rp. 18.050.400, nilai maksimum Rp. 504.084.487 dan nilai rata-rata sebesar Rp. 165.028.131,45. Pada Tabel 8 juga dapat dilihat standar deviasi yang menginformasikan variasi kelompok data pada masing-masing variabel, Modal pinjaman dengan standar deviasi paling tinggi yaitu sebesar Rp. 2.526.504.511,593
Hasil tersebut dapat diinterpretasikan:

1. Konstanta bernilai 3,443 dan bertanda positif menyatakan bahwa apabila nilai $X_{1}$ dan $\mathrm{X}_{2}$ dianggap nol maka $\mathrm{Y}$ sebesar Rp. 3.443.000.

2. Koefisien regresi modal sendiri $\left(X_{1}\right)$ sebesar 0,522 dan bertanda positif menyatakan bahwa apabila terjadi peningkatan modal sendiri sebesar Rp. 1.000.000, akan terjadi peningkatan SHU sebesar Rp. 522.000 dan sebaliknya. Artinya jika modal sendiri naik maka kemampuan usahanya akan

Tabel 7. Pertumbuhan Sisa Hasil Usaha Koperasi Kota Sukabumi Periode

2015-2016

\begin{tabular}{|c|c|c|c|c|}
\hline \multirow[t]{2}{*}{ No } & \multirow[t]{2}{*}{ Koperasi } & \multicolumn{2}{|c|}{ Sisa Hasil Usaha } & \multirow[t]{2}{*}{$\begin{array}{c}\text { Pertumbuhan } \\
(\%)\end{array}$} \\
\hline & & 2015 & 2016 & \\
\hline 1 & Mitra Setia & 64.246 .907 & 99.193 .986 & 54 \\
\hline 2 & Kokasyifa & 353.669 .814 & 504.084 .487 & 43 \\
\hline 3 & BMT Ibadurahman & 140.868 .135 & 289.189 .030 & 105 \\
\hline 4 & Usaha Kita & 182.873 .532 & 342.495 .329 & 87 \\
\hline 5 & Kowarsda & 33.526 .449 & 230.265 .845 & 587 \\
\hline 6 & Primkopad Kodim & 71.412 .350 & 73.604 .988 & 3 \\
\hline 7 & Mina Karya & 325.450 .000 & 478.275 .518 & 47 \\
\hline 8 & Warga & 63.032 .390 & 67.882 .399 & 8 \\
\hline 9 & Dewi Sartika & 72.662 .529 & 79.798 .809 & 10 \\
\hline 10 & Kerukunan & 45.685 .850 & 51.365 .000 & 12 \\
\hline \multirow[t]{2}{*}{11} & Triguna & 23.645 .873 & 35.615 .739 & 51 \\
\hline & Rata-Rata & 127.862 .110 & 204.706 .466 & 91 \\
\hline
\end{tabular}

Sumber : Dinas Perindustrian, Perdagangan \& Koperasi Kota Sukabumi (diolah),2017

\section{Hasil Estimasi Persamaan Regresi}

Penggunaan regresi berganda yaitu untuk menguji besaran pengaruh variabel-variabel independent terhadap variabel dependent.

$$
Y=3,443+0,522 X_{1}-0,008 X_{2}+\varepsilon
$$

meningkat, dengan begitu SHU akan naik.

3. Koefisien regresi modal pinjaman $\left(\mathrm{X}_{2}\right)$ sebesar $-0,008$ menyatakan bahwa jika modal pinjaman terjadi kenaikan sebesar Rp. 1.000.000, maka akan 
menurunkan SHU sebesar Rp. 8.000 dan sebaliknya. Artinya dengan bertambahnya modal pinjaman maka beban koperasi akan mengalami kenaikan, karena koperasi harus membayar bunga pinjaman dan mengembalikan pinjaman tersebut, sehingga dapat menyebabkan SHU koperasi menurun.

Berdasarkan persammaan regresi yang diperoleh bahwa nilai koefisien korelasinya $(r)$ antara variabel $X_{1}$ dan $X_{2}$ terhadap variabel $Y$ sebesar 0,548 ada pada hubungan cukup kuat akan naik dan akan meningkatkan SHU. Sejalan dengan penelitian dari Suteja (2016 : 8) bahwa secara simultan perolehan SHU dipengaruhi oleh modal sendri dan modal pinajaman.

Hasil perhitungan didapat nilai $\mathrm{t}_{\text {hitung }}$ untuk modal sendiri $\left(\mathrm{X}_{1}\right)$ sebesar 2,560 dengan taraf $\alpha=0,05$ dan tingkat kepercayaan sebesar 95 persen. Artinya modal sendiri $\left(\mathrm{X}_{1}\right)$ mempengaruhi positif dan nyata pada sisa hasil usaha (Y) koperasi Kota Sukabumi. Hasil ini sesuai penelitian Jabbar (2014: 12) bahwa modal sendiri $\left(\mathrm{X}_{1}\right)$ memiliki pengaruh

Tabel 8. Descriptive Statistics

\begin{tabular}{lccrrr}
\hline & $\mathrm{N}$ & Minimum & \multicolumn{1}{c}{ Maksimum } & \multicolumn{1}{c}{ Mean } & \multicolumn{1}{c}{ Std. Deviation } \\
\hline Modal sendiri & 22 & 58.574 .655 & 5.813 .429 .186 & $1.231 .670 .720, .32$ & $1.222 .270 .359,634$ \\
Modal pinjaman & 22 & 25.774 .000 & 10.482 .879 .665 & $1.257 .885 .341,73$ & $2.526 .504 .511,593$ \\
Sisa hasil usaha & 22 & 18.050 .400 & 504.084 .487 & $165.028 .131,45$ & $150.812 .265,618$ \\
$\begin{array}{l}\text { Valid N } \\
\text { (listwise) }\end{array}$ & 22 & & & & \\
\hline
\end{tabular}

\section{Hasil Uji Modal Sendiri Dan Modal Pinjaman pada Sisa Hasil Usaha (SHU) Koperasi Kota Sukabumi}

Berdasarkan hasil perhitungan pada tabel 9, menggunakan regresi berganda menunjukan bahwa variabel independent dapat memberikan sumabangan pengaruh sebesar 30 persen dari variabel dependent secara keseluruhan, Pada tingkat kepercayaan sebesar 95 persen. Nilai F-hitung sebesar 4,740 sehingga model ini cukup memadai untuk dijadikan alat analisis. Artinya secara simultan modal sendiri $\left(\mathrm{X}_{1}\right)$ dan modall pinajaman $\left(\mathrm{X}_{2}\right)$ mempunyai pengaruh secara positif dan nyata pada SHU (Y) koperasi Kota Sukabumi

Menurut Partomo (2002 : 76) bahwa jumlah modal yang digunakan mempengaruhi besarkecilnya usaha koperasi, apabila modal yang digunakan besar maka pendapatan koperasi positif dan nyata pada sisa hasil usaha (Y). Sedangkan nilai $t_{\text {hitung }}$ untuk modal pinjaman yaitu sebesar $-0,054$ dan nilai $t_{\text {tabel }}$ sebesar 2,085 Karena $t_{\text {hitung }}$ lebih keccil dari $t_{\text {tabel }}$ maha $\mathrm{H}_{\mathrm{o}}$ diterima dan $\mathrm{H}_{\mathrm{a}}$ ditolak. Nilai $\mathrm{t}$ negatif berarti modal pinjaman memiliki pengaruh berlawanan arah dengan SHU (Y), jadi dapat disimpulkan modal pinjaman $\left(\mathrm{X}_{2}\right)$ tidak mempengaruhi sisa hasil usaha (Y). penelitian ini sesuai penelitian Choiriyah (2005: 48). Hal ini diketahui dari nilai koefisien regresi modal pinjaman yaitu sebesar $-0,008$ yang bertanda negatif dengan nilai probabilitas 0,957 . Oleh karena $0,957>0,05$, hal ini berarti sisa modal pinjaman secara signifikan tidak mempengaruhi SHU, akan tetapi pengaruh modal pinjaman berbanding terbalik (negatif) sehingga semakin rendah modal pinjaman justru akan meningkatkan kualitas struktur modal koperasi tersebut. Riyanto (2001 : 23) menyebutkan permodalan yang baik didasari oleh modal sendiri, karena tahan 
resiko. Maka sebaiknya struktur finansial koperasi menetapkan jumlah modal sendiri ada, dan harus bisa meyakinkan anggotanya untuk mau

\section{Tabel 9. Rangkuman Hasil Perhitungan Data Koperasi Kota Sukabumi}

\begin{tabular}{|c|c|c|c|c|c|c|}
\hline & \multirow[t]{2}{*}{ Model } & \multicolumn{2}{|c|}{ Unstandardized Coefficients } & \multicolumn{2}{|l|}{ Standardized } & \multirow[t]{2}{*}{ Sig. } \\
\hline & & B & Std. Error & Beta & & \\
\hline \multirow{11}{*}{1} & (Constant) & 3,443 & 1,659 & & 2,075 &, 052 \\
\hline & Modal sendiri &, 522 & 204 & ,553 & 2,560 & 019 \\
\hline & Modal pinjaman &,- 008 & 141 &,- 012 &,- 054 & 957 \\
\hline & t-tabel & 2,085 & & & & \\
\hline & F-Hitung & 4,740 & & & & \\
\hline & Sig & 0,000 & & & & \\
\hline & F-Tabel & 4,35 & & & & \\
\hline & $\mathrm{R}$ & 0,548 & & & & \\
\hline & $\mathrm{R}^{2}$ & 0,300 & & & & \\
\hline & Adjusted $\mathrm{R}^{2}$ & 0,226 & & & & \\
\hline & SEE & 0,37533 & & & & \\
\hline
\end{tabular}

Sumber : Diolah,2017

sebaiknya lebih tinggi atas modal asing dalam keadaan apapun.

\section{KESIMPULAN DAN SARAN}

Berdasarkan uraian hasil penelitian maka disimpulkan bahwa :

1) Gambaran sisa/selisih hasil usaha dan modal sendiri secara umum mengalami kenaikan dengan kenaikan tertinggi terjadi pada SHU, dan yang mengalami kenaikan terendah adalah modal sendiri. Akan tetapi modal pinjaman mengalami penurunan. 2) Hasil Uji F, modal sendri dan modal pinjaman memiliki pengaruh positif dan nyata pada sisa hasil usaha koperasi Kota Sukabumi. 3) Hasil uji secara parsial didapatkan bahwa modal sendiri memiliki pengaruh positif dan nyata pada sisa hasil usaha koperasi Kota Sukabumi (Y). Akan tetapi modal pinjaman $\left(\mathrm{X}_{2}\right)$ tidak berpengaruh positif dan nyata pada SHU koperasi di Kota Sukabumi (Y).

Saran yang diberikan yaitu : 1) Bagi koperasi Kota Sukabumi sebaiknya mempertahankan kondisi struktur modal yang meningkatkan jumlah simpanan wajib atau simpanan pokok, agar koperasi dapat meningkatan modal sendiri. Mengingat hasil pennelitian diperoleh jika variabel modal sendiri berrpengaruh relatif besar kepada SHU. Selain itu dengan meningkatnya modal maka volume usaha koperasi meningkat juga yang memiliki dampak kepada kesejahteraan dan keuntungan para anggota koperasi. 2) Bagi peneliti selanjutnya agar memperluas cakupan sampel yang dipakai dan menambah periode kurun waktu penelitian serta bisa menambahkan variabel lain ini seperti : jumlah anggota, likuiditas, solvabilitas, dan lain-lain

\section{DAFTAR PUSTAKA}

Andjar, Pachta W, Dkk, 2005. Manajemen Koperasi (Teori dan Praktek). Graha Ilmu. Yogyakarta.

Choiriyah, Mailiya, 2005. Pengaruh Modal Sendiri Dan Modal Pinjaman Terhadap Sisa Hasil Usaha (SHU) Pada Koperasi Pegawai Republik 
Indonesia (KPRI) Se Kabupaten Demak.

Skripsi Sarjana, Fakultas Ilmu Sosial, Jurusan Ekonomi, Universitas Negeri Semarang.

Ghozali, Imam, 2011. Aplikasi Analisis Multivariate dengan Program IBM SPSS 19 (edisi kelima). Universitas Diponegoro. Semarang.

Gitosudarmo, Indriyo dan Basri, 2000, Manajemen Keuangan Edisi Ketiga, BPFE, Yogyakarta.

Hanafi, Mamduh M, 2008. Manajemen Keuangan (Edisi 1). BPFE. Yogyakarta.

Hanel, Alfred, 1989. Pokok-Pokok Pikiran Mengenai Organisasi Koperasi dan Kebijakan Pengembangan di Negaranegara Berkembang. Edisi Pertama, Universitas Padjadjaran, Bandung.

Hendrojogi, 1997, Koperasi (Teori dan Praktek), Raja Grafindo Persada, Jakarta.

Husnan, Suad, 2008, Manajemen Keuangan (Teori dan Penerapan), BPFE, Yogyakarta.

Keputusan Menteri Koperasi dan UMKM Nomor: 129/KEP/M.KUKM/XI/2002, Tanggal 19 Nopember 2002 tentang Pedoman Klasifikasi Koperasi.

Martono, dan Harjito, D. Agus, 2010, Manajemen Keuangan, Ekonosia Kampus Fakultas Ekonomi UII, Yogyakarta.

Partomo, dkk, 2004, Ekonomi Skala Kecil Atau Menengah Dan Koperasi, Ghalia Indonesia, Bogor.
Pernyataan Standar Akuntansi Keuangan No. 27 Tentang Akuntansi Perkoperasian (IKATAN AKUNTAN INDONESIA 1999).

Praba Suteja, Gede, 2016, Pengaruh Jumlah Modal Sendiri Dan Jumlah Modal Pinjaman Terhadap Perolehan Sisa Hasil UsahaPada Kpn Praja Mukti Kantor Bupati Buleleng Tahun 20062015, Jurnal Program Studi Pendidikan Ekonomi (JPPE) Vol. 7 No. 2.

Rahayu, Listia Puji, 2011, Pengaruh Modal Sendiri dan Modal Pinjaman Terhadap Perolehan Sisa Hasil Usaha pada KPRI di Kabupaten Pati. Skripsi Sarjana, Fakultas Ekonomi Universitas Negeri Semarang.

Riyanto, 2001, Dasar-Dasar Pembelanjaan Perusahaan, BPFE- UGM, Yogyakarta. , 2008, Dasar-Dasar Pembelanjaan Perusahaan (Edisi 4), BPFE-UGM, Yogyakarta.

Rozi dan Hendri, 1997, Kapan dan Bilamana Berkoperasi, Unri Press. Riau.

Sitio, Arifin dan Halomoan Tamba, 2001, Koperasi, (Teori dan Praktek), Erlangga Jakarta.

Subandi, 2009, Ekonomi Koperasi Teori, Alpabeta, Bandung.

Sugiyono. 2013. Metode Penelitian Kualitatif, Kuantitatif dan Kombinasi, Edisi ketiga. Bandung. Alfabeta.

Sukamdiyo, 1997, Manajemen Koperasi, Erlangga, Jakarta.

Undang-Undang Republik Indonesia, No.25 Tahun 1992, Tentang Perkoperasian 